\title{
Yoğun Bakımda Illaç ile Özkıyım Nedeni ile Takip Edilen Olguların Analizi ve Illaca Ulaşım Yolları: Tek Merkezli Prospektif Bir Çalışma
}

\author{
Evaluation of Patients Hospitalized in Intensive Care Unit Due to \\ Drug-Related Suicide Attempt and Access to Drugs: A Single Center \\ Prospective Study
}

\author{
Fatih Doğu Geyik, Gülbin Töre Altun*, Necati Çitak**, Tülin Akarsu Ayazoğlu***, \\ Yaşar Gökhan Gül****, Mehmet Toptaş ${ }^{\star \star \star * \star *}$ \\ S. B. Dr. Lütfi Kırdar Kartal Eğitim ve Araştırma Hastanesi, Anesteziyoloji ve Reanimasyon Kliniği, Istanbul, Türkiye \\ ${ }^{*}$ Kars Devlet Hastanesi, Anesteziyoloji ve Reanimasyon Kliniği, Kars, Türkiye \\ **Kars Devlet Hastanesi, Göğüs Cerrahisi Kliniği, Kars, Türkiye \\ ***Kartal Koşuyolu Yüksek Ihtisas Eğitim ve Araştırma Hastanesi, Anesteziyoloji ve Reanimasyon Kliniği, İstanbul, Türkiye \\ ****Arnavutköy Devlet Hastanesi, Anesteziyoloji ve Reanimasyon Kliniği, İstanbul, Türkiye \\ *****Haseki Eğitim ve Araştırma Hastanesi, Anesteziyoloji ve Reanimasyon Kliniği, İstanbul, Türkiye
}

\section{Özet}

Amaç: Bu çalışma bir yıllık süre içinde yoğun bakım ünitemizde (YBÜ) ilaç alımı (medikal veya tarım ilacı) ile özkıyım girişiminde bulunan olguları ve ilaca ulaşım yollarını incelemektir.

Yöntemler: Özkıyım girişiminde bulunan 50 olgunun (32'si kadın, $18^{\prime} i$ erkek) demografik verileri ve tıbbi özellikleri prospektif olarak kaydedilmiştir.

Bulgular: Yaş ortalaması 25,4 $\pm 8,8$ olan olguların \%66'sı 15-24 yaş arasındaydı. Olguların \%28'inde çoklu ilaç kullanımı mevcuttu. Işsizliğin kadınlarda daha fazla olduğu saptandı $(p<0,001)$. Erkeklerin özkıyım için kullandıkları ilacı \%27,8 oranında eczaneden aldıkları saptanır iken kadınlar için bu oran \%6,2 idi $(p=0,03)$. Olguların $\% 86^{\prime}$ sı $(n=43)$ ve kadın olguların \%93'ü $(n=30)$ ilacı evdeki ilaç deposundan kullanmışlardı. Eczaneden ilaç alan olguların evdeki ilacı kullanan olgulara göre istatistiksel olarak anlamlı düzeyde daha fazla toksik düzeye ulaştığı saptandı $(p=0,06)$. Toksik düzeye ulaşan hastalarda yoğun bakım ünitesinde kalış süresi toksik düzeye ulaşmayanlara göre istatistiksel olarak anlamlı bulundu $(p=0,001)$.

Sonuç: ilaç alımı ile takip ettiğimiz olguların çoğu evlerinde bulunan ilaçlardan ve tarım ilaçlarından faydalanmışlardı. Özkıyım girişimi riski bulunan hastaların ilaca ulaşımlarında önlemler alınması ile beraber kamu düzenlemelerinin gerektiği kanısındayız. (Haseki Tıp Bülteni 2014; 52: 111-5)

Anahtar Sözcükler: Özkıyım, yoğun bakım, ilaç kötüye kullanımı
Abstract

Aim: We aimed to evaluate patients who were hospitalized in our intensive care unit due to drug-related suicide attempt (medical or insecticides) and their access to these drugs.

Methods: We prospectively recorded the demographic characteristics and medical data of 50 patients (32 females and 18 males) who were hospitalized in our intensive care unit due to drug-related suicide attempt. Results: $66 \%$ of subjects were between the ages of 15 and 24 years with a mean age of $25.4 \pm 8.8$ years. Multiple drug overdose was observed in $28 \%$ of patients. The unemployment rate was higher for women than men $(p<0.001)$. Men obtained drugs from pharmacy more often than women $(27.8 \%$ vs $6.2 \%, p=0,03)$. Of the patients, $86 \%$ got the drugs from home medicine cabinet while this rate was $93 \%$ among women $(n=30)$. The level of toxicity was higher among patients who got the drugs from pharmacy than in those who used drugs at home $(p=0.06)$. The length of stay in the intensive care unit was longer among patients with toxic level of medication $(p=0.001)$

Conclusion: Patients usually use drugs or insecticides available at home to commit suicide. We believe that in patients with risk of suicide attempt, access to drugs should be limited and state regulations should be applied. (The Medical Bulletin of Haseki 2014; 52:111-5)

Key Words: Suicide, intensive care, drug abuse
Yazışma Adresi/Address for Correspondence: Yaşar Gökhan Gül Arnavutköy Devlet Hastanesi, Anesteziyoloji ve Reanimasyon Kliniği, İstanbul, Türkiye E-posta: doctorgul@yahoo.com

Geliş Tarihi/Received: 09 Ekim 2013 Kabul Tarihi/Accepted: 27 Ekim 2013
Haseki Tıp Bülteni,

Galenos Yayınevi tarafından basılmıştır.

The Medical Bulletin of Haseki Training and Research Hospital, published by Galenos Publishing. 


\section{Giriş}

Özkıyım; bireyin istemli olarak yaşamına son verme davranışıdır. Tüm dünyada olduğu gibi ülkemizde ergenlik döneminde özkıyım vakalarında artış görülmektedir (13). Özkıyım girişimlerinin temel nedenleri arasında fiziksel ve ruhsal bozukluklar, aile içi geçimsizlikler, geçim sıkıntısı gibi sosyal ve ekonomik nedenler gösterilmektedir $(4,5)$. Sıralaması ülkelere göre değişiklik göstermekle beraber ilaç alımı ile özkıyım girişimi ilk üç sıra içinde bulunmaktadır $(6,7)$.

Çalışmamızda son bir yılda ilaç alarak özkıyım girişiminde bulunup genel yoğun bakım ünitemizde takip edilen hastaların demografik verilerinin analizleri ve ilaca ulaşım yolları değerlendirilmiştir. Ayrıca Sağlık Bakanlığı́nın evdeki atıl ilaçların toplatılmasına yönelik çalışmalarına ışık tutması ve ilaç kötüye kullanımlarının önüne geçilmesi amaçlanmıştır.

\section{Yöntemler}

Bu çalışma 2012 yılı içerisinde ilaç alımı (medikal veya tarım ilacı gibi) ile özkıyım girişiminde bulunup Kars Devlet Hastanesi 1.-3. basamak genel yoğun bakım ünitesinde yatırılarak takip edilen olguları kapsamaktadır. Yanlışılıkla kimyasal madde veya ilaç alımı, kendini asma, yüksekten atma gibi özkıyım girişimleri çalışmaya dahil edilmedi. Bir yıllık süreçte kimyasal madde ile özkıyım gerçekleştiren 50 olgunun bilgileri prospektif olarak kaydedildi.

Yoğun bakıma yatan hastaların genel durumu stabilize edildikten sonra fizik muayene dikkatli bir şekilde yapıldı. Hastaların fizik muayenesinde; karakteristik koku varlığı, cilt rengi ve nefes kokusu, pupil bulguları, tansiyon ve kalp ritm durumu, nöromüsküler anormallikleri, bilinç durumu, vücut ISISI değişimleri, solunum sistemi bulguları değerlendirildi. Fizik muayenede zehirlenme hakkında ipucu verebilecek bulgulara ve eşlik eden bir travma olup olmadığına dikkat edildi, özellikle bilinci bozulmuş hastalarda vakit kaybedilmeden, zehirlenmeye eşlik eden bir travmanın varlığı, yüksek doz ilaç ya da madde kullanımına bağlı zehirlenme tablosunun olup olmadığı incelendi.

Hastalarda rutin olarak serum ozmolalitesi ve ozmolar gap, elektrolitler, kan şekeri, üre, kreatinin, KCFT, EKG Idrar tetkiki, protrombin zamanı ve aktivitesi, arteryal kan gazları tetkikleri yapıldı. Yapılan rutin biyokimyasal tetkikler baseline değerler olarak kaydedildi. Tanısal veya medikolegal amaçla $50 \mathrm{ml}$ idrar (ilk idrardan $50 \mathrm{ml}$ ), kan (10 ml heparinize, $10 \mathrm{ml}$ heparinsiz kan örneği) alındı.

Özkıyım eylemlerinde alınan toksik maddenin bilinmediği durumlar, multipl madde alımının söz konusu olduğu durumlar, semptomlar ile fizik muayene bulgularının öykü ile uyumlu olmadığı ve ciddi klinik tabloyla seyreden durumlarda kalitatif toksikolojik tarama testleri, asetaminofen, salisilatlar, etanol, etilen glikol, isopropil alkol, digoksin, demir, lityum, teofilin, antikonvülzanlar ve metanol gibi maddeler ile oluşan zehirlenmelerde serum ilaç düzeyinin saptanması amaçlarıyla kantitatif toksikolojik tarama testleri uygulandı.

Çalışma, veri toplama ve bu verilerinin değerlendirilmesi üzerine kurulduğu için sadece hastane yönetiminden izin alınmıştır. Ayrıca verilerin toplanması sırasında hasta ve hasta yakınlarından gerekli onamlar alınmıştır.

Olguların demografik verileri, yaşadıkları yer, eğitim durumları, psikiyatrik hastalık öyküsü, daha önceden özkıyım öyküsü, çalışma durumu, toksik düzeye ulaşma durumu, kullanılan kimyasal madde ve bu maddelere ulaşım şekilleri not edilmiştir. Bilgiler hasta ve hasta yakınları ile görüşülerek kaydedilmiştir.

\section{İstatistiksel Analiz}

Veriler "SPSS for Windows 15.0" programına girildi. Gruplar arasındaki karşılaştırma için student t-testi ve ki-kare testi (örnek sayısı yetersizse fisher exact test) kullanıldı. $P<0,05$ değeri istatistiksel olarak anlamlı kabul edildi.

\section{Bulgular}

Yaş ortalaması $25,4 \pm 8,8$ olan olguların 4'ü (\%8) evli (ev hanımı), 25'si bekar (işsiz-öğrenci kadın \%50), 3'ü çalışan kadın (\%6) ve 18'i erkek (\%36) idi. Yüzde 66'sı ( $\mathrm{n}=33$ ) 15-24 yaş arasındaydı. Illköğretim mezunu olan 19 olgu (\%38), lise mezunu olan 26 olgu (\%52) ve üniversite mezunu olan beş olgu (\%10) mevcuttu. Olguların $\% 46$ 'sı köy (\%14) veya ilçede (\%32) yaşarken, \%54'ü il merkezinde yaşıyordu. Hikayesinde önceden bir psikiyatrik hastalık öyküsü olan ve bu hastalığa özgü ilaç kullanan olgu sayısı 19 idi (\%38). Olguların \%16'sı (n=8) daha önceden de özkıyımı denemişti. Çalışma durumlarına bakıldığında çoğunluğunun işsiz olduğu ( $n=28, \% 56)$ görüldü. Özkıyım için kullanılan ilaçların sıklıkla (\%86) evde mevcut olan ilaçlardan oluştuğu saptandı.

On dört olguda (\%28) çoklu ilaç kullanımı mevcuttu. Bu olguların $11^{\prime} i$ evdeki ilaçları kullanmış iken geri kalan üçü ilaca eczaneden ulaştıklarını belirtmişlerdi. On üç olgu tarım ilacı (\%26), dokuz olgu antidepresan-antipsikotik (\%18), yedi olgu analjezik (\%14) ve kalan yedi olgu diğer (antihipertansif, kardiyolojik, antiepileptik) ilaçlar ile özkıyım gerçekleştirmiş̧ti (Şekil 1).

Cinsiyetler arasında yaş, eğitim düzeyi, yaşanılan yer, psikiyatrik hastalık öyküsü, daha önceden özkıyım hikayesi, toksik düzeye ulaşma ve çoklu ilaç kullanımı açısından istatistiksel olarak anlamlı fark saptanmadı (Tablo 1). Işsizliğin kadınlarda daha fazla olduğu (\%78,1'e karşılık $\% 16,7, p<0,001)$ görüldü. Erkekler özkıyım için kullandığı ilacı \%27,8 oranında eczaneden alır iken kadınlarda bu oran $\% 6,2$ idi $(p=0,03)$.

On dört olgunun (\%28) toksik düzeye ulaştığı görüldü. $\mathrm{Bu}$ olguların ikisinde hemodiyaliz gerekti. Üç buçuk aylık hamile olan bir olguda gebeliğin sonlandırılması 
gerekti. Yaş, eğitim düzeyi, yaşanılan yer, psikiyatrik hastalık öyküsü, daha önceden özkıyım hikayesi, çalışma durumu ve çoklu ilaç kullanımı toksik düzeye ulaşmayı etkilemiyordu (Tablo 2). Ancak eczaneden aldıkları ilaçlar ile özkıyım gerçekleştiren olgularda istatistiksel olarak anlamlı düzeyde daha fazla toksik düzeye ulaşma saptandı $(p=0,06)$ (Tablo 2).

Tüm olguların YBÜ'de yatış süreleri 1,62 $\pm 0,63$ idi. YBÜ'de kalış süresi toksik düzeye ulaşan olgularda toksik düzeye ulaşmayanlara göre istatistiksel olarak anlamlı düzeyde daha fazla bulundu $(p=0,001)$.

Mortalite bir olguda gerçekleşti (\%2). Bu olgu şüpheli tarım ilacı alımı sonrası takibinin dördüncü gününde kaybedildi.

\section{Tartışma}

Ülkemizde özkıyım giderek artan bir halk sağlığı sorunu olmakla beraber genç kuşakta önlem alınması gereken bir problemdir (2). Çalışmamızda özkıyım davranışı değerlendirilir iken sadece ilaç kullanan hastalar dahil edilmiş olup, bu hastaların psikiyatrik geçmişleri, eğitim durumları gibi faktörlerin yanında ilaca ulaşım yolları değerlendirilmeye çalışıımıs ve ilaç kötüye kullanımlarının önüne geçilmesi amaçlanmıştır.
Olguların büyük çoğunluğu 15-24 yaş (\%66) arasındaydı. Bu yaş grubu ergenlik ve geç ergenlik dönemini kapsamaktadır. Bu dönem yerleşik bir dönem olmayıp ayrıma bireyselleşme çabalarının başladığı, fiziki ve psikolojik olarak değişimlerin yaşandığı bir dönemdir. Yurt içi ve yurt dışı yayınlar göstermiştir ki bu yaş grubunda özkıyım riski yüksektir (8-12).

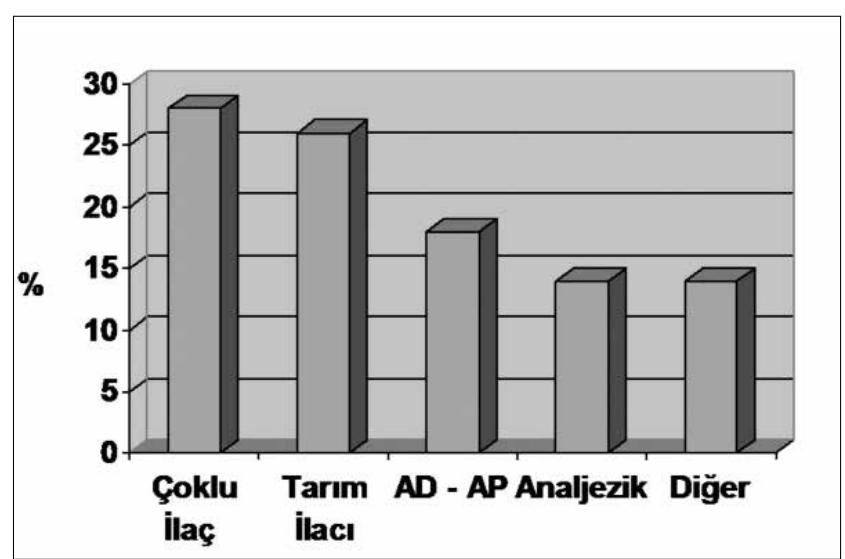

Şekil 1. Özkıyım amaçlı kullanılan ilaçların dağılımı (\%)

\begin{tabular}{|c|c|c|c|c|}
\hline & Erkek $(n=18)$ & Kadın $(n=32)$ & $\begin{array}{l}\text { Toplam } \\
(n=50)\end{array}$ & p değeri \\
\hline Yaş & $26,5 \pm 9,3$ & $24,8 \pm 8,6$ & $25,4 \pm 8,8$ & 0,525 \\
\hline $\begin{array}{l}\text { Eğitim düzeyi } \\
\text { Illköğretim } \\
\text { Lise } \\
\text { Üniversite }\end{array}$ & $\begin{array}{l}5(\% 27,8) \\
10(\% 55,6) \\
3(\% 16,7)\end{array}$ & $\begin{array}{l}14(\% 43,8) \\
16(\% 50,0) \\
2(\% 6,3)\end{array}$ & $\begin{array}{l}19(\% 38,0) \\
26(\% 52,0) \\
5(\% 10,0)\end{array}$ & 0,162 \\
\hline $\begin{array}{l}\text { Yaşadığı yer } \\
\text { Köy } \\
\text { İlçe } \\
\text { III Merkezi }\end{array}$ & $\begin{array}{l}2(\% 11,1) \\
6(\% 33,3) \\
10(\% 55,6)\end{array}$ & $\begin{array}{l}5(\% 15,6) \\
10(\% 31,3) \\
17(\% 53,1)\end{array}$ & $\begin{array}{l}7(\% 14,0) \\
16(\% 32,0) \\
27(\% 54,0)\end{array}$ & 0,746 \\
\hline $\begin{array}{l}\text { Psikiyatrik hastalık öyküsü } \\
\text { Var } \\
\text { Yok }\end{array}$ & $\begin{array}{l}8(\% 44,4) \\
10(\% 55,6)\end{array}$ & $\begin{array}{l}11(\% 34,4) \\
21(\% 65,6)\end{array}$ & $\begin{array}{l}19(\% 38,0) \\
31(\% 62,0)\end{array}$ & 0,481 \\
\hline $\begin{array}{l}\text { Daha önceden öz kıyım } \\
\text { Var } \\
\text { Yok }\end{array}$ & $\begin{array}{l}3(\% 16,7) \\
15(\% 83,3)\end{array}$ & $\begin{array}{l}5(\% 15,6) \\
27(\% 84,4)\end{array}$ & $\begin{array}{l}8(\% 16,0) \\
42(\% 84,0)\end{array}$ & 0,923 \\
\hline $\begin{array}{l}\text { Çalışma durumu } \\
\text { Çalışıyor } \\
\text { İşsiz }\end{array}$ & $\begin{array}{l}15(\% 83,3) \\
3(\% 16,7)\end{array}$ & $\begin{array}{l}3(\% 9,6) \\
29(\% 93,5)\end{array}$ & $\begin{array}{l}18(\% 44,0) \\
31(\% 56,0)\end{array}$ & $<0,001$ \\
\hline $\begin{array}{l}\text { İlaca ulaşım şekli } \\
\text { Ev } \\
\text { Eczane }\end{array}$ & $\begin{array}{l}13(\% 72,2) \\
5(\% 27,8)\end{array}$ & $\begin{array}{l}30(\% 93,8) \\
2(\% 6,2)\end{array}$ & $\begin{array}{l}43(\% 86,0) \\
7(\% 14,0)\end{array}$ & 0,03 \\
\hline $\begin{array}{l}\text { Toksik düzey } \\
\text { Var } \\
\text { Yok }\end{array}$ & $\begin{array}{l}6(\% 33,3) \\
12(\% 66,7)\end{array}$ & $\begin{array}{l}8(\% 25,0) \\
24(\% 75,0)\end{array}$ & $\begin{array}{l}14(\% 28,0) \\
36(\% 72,0)\end{array}$ & 0,529 \\
\hline Mortalite & $0(\% 0)$ & $1(\% 3,1)$ & $1(\% 2)$ & 0,449 \\
\hline
\end{tabular}




\begin{tabular}{|c|c|c|c|c|}
\hline & \multicolumn{3}{|c|}{ Toksik düzey } & \multirow[b]{2}{*}{ p değer } \\
\hline & $\operatorname{Var}(n=14)$ & Yok $(n=36)$ & Toplam $(n=50)$ & \\
\hline Yaş & $25,6 \pm 9,3$ & $25,4 \pm 8,7$ & $25,4 \pm 8,8$ & 0,936 \\
\hline $\begin{array}{l}\text { Eğitim düzeyi } \\
\text { IIlköğretim } \\
\text { Lise } \\
\text { Üniversite }\end{array}$ & $\begin{array}{l}4(\% 28,6) \\
8(\% 57,1) \\
2(\% 14,3) \\
\end{array}$ & $\begin{array}{l}15(\% 41,7) \\
18(\% 50,0) \\
3(\% 8,3)\end{array}$ & $\begin{array}{l}19(\% 38,0) \\
26(\% 52,0) \\
5(\% 10,0)\end{array}$ & 0,345 \\
\hline $\begin{array}{l}\text { Yaşadığı yer } \\
\text { Köy } \\
\text { İlçe } \\
\text { il Merkezi }\end{array}$ & $\begin{array}{l}2(\% 14,3) \\
5(\% 35,7) \\
7(\% 50,0) \\
\end{array}$ & $\begin{array}{l}5(\% 13,9) \\
11(\% 30,6) \\
20(\% 53,1) \\
\end{array}$ & $\begin{array}{l}7(\% 14,0) \\
16(\% 32,0) \\
27(\% 54,0) \\
\end{array}$ & 0,795 \\
\hline $\begin{array}{l}\text { Psikiyatrik hastalık öyküsü } \\
\text { Var } \\
\text { Yok }\end{array}$ & $\begin{array}{l}5(\% 35,7) \\
9(\% 64,3)\end{array}$ & $\begin{array}{l}14(\% 38,9) \\
21(\% 61,1)\end{array}$ & $\begin{array}{l}19(\% 38,0) \\
31(\% 62,0)\end{array}$ & 0,836 \\
\hline $\begin{array}{l}\text { Daha önceden öz kıyım } \\
\text { Var } \\
\text { Yok }\end{array}$ & $\begin{array}{l}3(\% 21,4) \\
11(\% 78,6)\end{array}$ & $\begin{array}{l}5(\% 13,9) \\
31(\% 86,1)\end{array}$ & $\begin{array}{l}8(\% 16,0) \\
42(\% 84,0)\end{array}$ & 0,670 \\
\hline $\begin{array}{l}\text { Çalışma durumu } \\
\text { Çalışıyor } \\
\text { İşsiz }\end{array}$ & $\begin{array}{l}5(\% 35,7) \\
9(\% 64,3)\end{array}$ & $\begin{array}{l}17(\% 47,2) \\
19(\% 52,8)\end{array}$ & $\begin{array}{l}22(\% 44,0) \\
28(\% 56,0)\end{array}$ & 0,462 \\
\hline $\begin{array}{l}\text { Illaca ulaşım şekli } \\
\text { Ev } \\
\text { Eczane }\end{array}$ & $\begin{array}{l}14(\% 71,4) \\
4(\% 28,6)\end{array}$ & $\begin{array}{l}33(\% 91,7) \\
3(\% 8,3)\end{array}$ & $\begin{array}{l}43(\% 86,0) \\
7(\% 14,0)\end{array}$ & 0,06 \\
\hline Mortalite & $1(\% 7,1)$ & $0(\% 0)$ & $1(\% 2)$ & 0,280 \\
\hline Yatış süresi & $2,07 \pm 0,61$ & $1,44 \pm 0,55$ & $1,62 \pm 0,63$ & 0,001 \\
\hline
\end{tabular}

Çalışmamızda kadın erkek oranı 2:1 olarak gözlemlenmiştir. İşsizliğin özkıyım girişiminde bulunan kadınlarda anlamlı düzeyde daha fazla olduğu saptanmıştır. Kadınların erkeklere göre daha yüksek olduğu bu oran hem yurtiçi hem de yurtdışı benzer çalışmalarda da saptanmıştır (6-8). Kadın hasta grubunun büyük çoğunluğunun işsiz (ev hanımı-öğrenci) olması, ülkemizdeki şartlar göz önüne alındığında kadınların kendilerini ifade etmedeki yetersizlikleri, cinsel istismara maruz kalmaları, ekonomik bağımsızlıklarının olmayışı ve sosyal şartlardaki yetersizliklerle açıklanabilir. Tüm bu etkenler kadınlarda depresyon tanısının erkeklerden fazla görülmesine neden olmaktadır. Buna bağıı olarak özkıyım kadınlarda daha sık görülüyor olabilir (9).

Özkıyım gerçekleştiren kadınların \%6'sının meslek sahibi olduğunu saptadık. Kadınların sosyal hayatın içinde olması ve ekonomik bağımsızlığını kazanmasının bu oranı düşürdüğünü düşünmekteyiz. Kadın olgularımızın çok azının üniversite mezunu olması, eğitim düzeyinin artışına paralel olarak özkıyım oranının azaldığını düşündürse de çalışmanın yapıldığı bölgenin sosyokültürel düzeyinin tüm bu oranları etkilediği unutulmamalıdır.

Kapalı ve geleneksel toplum yapısına sahip olma, bireyin kendini ifade etmede ve kimliğini ortaya koymada kullandığı davranış kalıplarını etkileyerek, aile geçimsizliği ve aile içi şiddeti arttırarak özkıyım riskini arttırmaktadır. Bu yüzden kırsal nüfusta daha fazla intihar olgusu görülmesi beklenebilir. Ancak hem bizim çalısmamızda (\%54) hem de yayınlanan diğer çalışmalarda intihar edenlerin sıklıkla şehir merkezinde yaşadıkları görülmektedir. Bu durum kırsalda özkıyımın gizlenmesi nedeni ile olabilir. Ayrıca son on yılda artış gösteren köyden kente göç oranı ile de ilişkilendirilebilir.

Kreitman (13) intihar düşüncesi içinde girişilen ancak sonunda ölüm olmayan davranışları parasuisid olarak tanımlamıştır. Ülkemizde son yıllarda yapılan çalışmalar parasuicid oranındaki artışı göstermektedir (14). Çalışmamızdaki 50 olgunun sadece birinde ölüm gerçekleşmesi ve olguların sadece \%28'inde toksik düzeye ulaşımın saptanması intiharların büyük kısmının parasuisidal girişimler olduğunu desteklemektedir.

Psikiyatrik hastalık öyküsü olanların olmayanlara göre özkıyım riskinin 3-12 kat arttığı ve özkıyım olgularının \%19-\%24'ünde daha önceden özkıyım girişimi öyküsünün mevcut olduğu gösterilmiştir (15). Olgularımızın \%38'inde $(n=19)$ tanı konulmuş psikiyatrik hastalık hikayesi mevcuttu. Bu olguların sekizi daha önceden özkıyım girişiminde bulunmuşlardı.

Özkıyımın özellikle (\%86) evde ilaçlar (medikal ve tarım ilacı gibi) ile gerçekleştirildiğini saptadık. Bunun sebebi ülkemizde ilaçların hekimlerce belirtilen süreden daha kısa süre kullanılması olabilir. Böylelikle ilaç 
kutusundaki ilaçların hepsi tüketilmemekte ve bu ilaçlar dolaplarda tutulmaktadır. Bu durum ilçe ve köylerde hastaların ilaçlarını sağlık kurumları yerine komşudan temin etmelerine sebep olmaktadır. Ayrıca eczanelerde reçetesiz ilaç satılması ve ülkemizde halen bazı ilaçların mahalle bakkalında satııyor olması da bir diğer etmendir. Bu durumlar evde bulunan ilaç çeşitliliğini arttırmakta ve özkıyım amacıyla çoklu ilaç alınmasını tetiklemektedir. Böylece ilaçlar arası etkileşim de çözülmesi gereken ayrı bir sorun olarak ortaya çıkmaktadır. Çalışmamızda çoklu ilaç ile özkıyım gerçekleştiren 14 hastanın 11'i özkıyımı evde bulunan ilaçlar ile gerçekleştirmişti. Köylerde kullanılan tarım ve hayvan ilaçlarının kontrole tabi olmaması köylerde bu ilaçlarla özkıyımın artışına sebep olabilir. Tarım ilacı ile gerçekleştirilen özkıyım oranını \%26 olarak saptadık.

Sonuç olarak daha öncesinde psikiyatrik hastalık tanısı olan, özkıyım hikayesi gibi risk faktörleri olan bireylerin ilaca ulaşım yollarının gerek aile içi bilgilendirme, gerek kamu düzenlemeleri ile kontrol altına alınmasını önermekteyiz. Kadının sosyal hayatta etkin rol alması, sivil toplum kuruluşları ve kamu kurumlarının işbirliği ile bölgemizde özkıyım olgularının azalacağını düşünüyoruz.

\section{Kaynaklar}

1. Sayıl I. Intihar davranışı ve epidemiyolojisi. O Doğan (ed): Psikiyatrik Epidemioloji'de, İzmir, Ege Psikiyatri Yayınları, 1995, s.118-23.

2. Sayar K, Bozkır F. Intihar girişiminde bulunan ergenlerde intihar niyeti ve ölümcüllüğün belirleyicileri. Yeni Symposium 2004;42:28-36.

3. Aycan S, Tümay Ş, Şimşek Z. İntiharın Önlenmesi. Ankara, Sağlık Bakanlığı, 2000.
4. Başbakanlık Devlet İstatistik Enstitüsü: 2000 Intihar İstatistikleri, Ankara. Başbakanlık Matbaası, 2000.

5. Sayil I, Devrimci-Ozguven H; WHO/EURO Multicentre Study of Suicidal Behaviour. Suicide and suicide attempts in Ankara in 1998: results of the WHO/EURO Multicentre Study of Suicidal Behaviour. Crisis 2002;23:11-6.

6. Fawcett J, Shaughnessy R. The suicidal patient. JA Flaherty, RA Channon, JM Davis (eds), Psychiatry'de, Chicago, 1989, s.49-56.

7. Welch SS. Areview of the literature on the epidemiology of parasuicide in the general population. Psychiatr Serv 2001; 52:368-75.

8. Şenol V, Ünalan D, Avşaroğulları L, ikizceli i. İntihar girişimi nedeniyle Erciyes Üniversitesi Tıp Fakültesi Acil Anabilimdalı'na başvuran olguların izlenmesi. Anadolu Psikiyatri Dergisi 2005;6:19-29.

9. Beautrais AL, Joyce PR, Mulder RT. Personality traits and cognitive styles as risk factors for serious suicide attempts among young people. Suicide Life Threat Behav 1999;29:3747.

10. Akın $D$, Tüzün $Y$, Çil T. Türkiye'nin güneydoğusundaki akut zehirlenme olgularının profili. Dicle Tıp Dergisi 2007;34:1958.

11. Ercan ES. Intihar girişiminde bulunmuş ergenlerin psikiyatrik değerlendirmesinde nelere dikkat edilmeli? Psikiyatri Bülteni 1996;4:124-7.

12. Williams-Johnson J, Williams $E$, Gossell-Williams $M$, Sewell CA, Abel WD, Whitehorne-Smith PA. Suicide attempt by self-poisoning: characteristics of suicide attempters seen at the Emergency Room at the University Hospital of the West Indies. West Indian Med J 2012;61:526-31.

13. Kreitman N, Philip AE, Greer $S$, Bagley CR. Parasuicide. 1969;115:746-7.

14. Devrimci Özgüven H, Sayıl I. Suicide attempts in Turkey: results of the WHO-EURO Multicentre Study on Suicidal Behaviour. Can J Psychiatry 2003;48:324-9.

15. Roy A. Psychiatric Emergencies BJ Sadock, VA Sadock (eds): Comprehensive Textbook of Psychiatry. 7th edition, Baltimore, Lippincott Williams \& Wilkins, 2000; 2031-2040. 